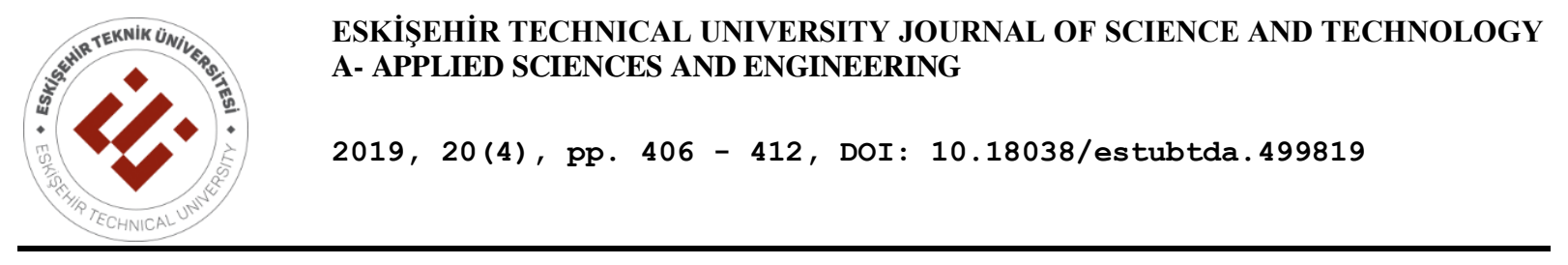

\title{
A STUDY ON THE INVESTIGATION OF IMPROVEMENT IN COAL LIQUEFACTION PRODUCT EFFICIENCY
}

\author{
Aydan AKSOĞAN KORKMAZ ${ }^{1, *}$ İsmail BENTLí ${ }^{2}$ \\ ${ }^{1}$ Department of Mining Technology, Malatya Turgut Özal University, Malatya, Turkey \\ 2 Department of Mining Engineering, İnönü University, Malatya, Turkey
}

\begin{abstract}
The aim of this study is to improve the yields of Malatya-Arguvan lignite liquefaction products (char, preasphaltene, asphaltene, oil-gas). For this purpose, the liquefaction experiments of coal which was firstly raw and then enriched by spiral have been carried out. The chemical characterizations of the obtained products have been determined by proximate and ultimate analysis. The composition of the oil was identified by GC-MS. As a result of the enrichment, the char yield decreased by $9.28 \%$ whereas the preasphaltene yield increased by $5.31 \%$ and the oil + gas yield increased by $4.18 \%$. Total conversion increased from $47.57 \%$ to $56.85 \%$. It has been concluded that the enrichment process has a positive effect on the liquefaction yields.
\end{abstract}

Keywords: Liquefaction, Lignite, Asphaltane, Preasphaltane, Char, Oil

\section{INTRODUCTION}

According to the Energy Current Policies Scenario in of the International Energy Agency; increase rates for energy resources in $2017-2040$ period; $42.8 \%$ in coal, $49.5 \%$ in natural gas, $16.9 \%$ in oil, $73 \%$ in nuclear, and $124.7 \%$ in renewable energy and others. Therefore, it is seen that the position of coal in the world energy supply will not change in the next 20 years [1].

The current reports of the MTA (Mineral Exploration and Exploration) indicate that the total coal resources in Turkey (including lignite, asphaltite and hard coal) is 18.77 billion tons. As one third of the coal resources of our country have been completed the feasibility studies, only a small part of them are considered as reserves [2].

Because of the organic and inorganic compounds contained in coal, it is important not only to meet the energy need but also to be a source of chemical raw materials. For this reason, various processes such as pyrolysis and liquefaction have been tried to produce solid and liquid fuels or chemical raw materials from coal. There are many studies on this subject in the literature [3-9].

The structure of coal is different from that of the hydrocarbons in petroleum. The principal difference between coal and petroleum is due to the lower $\mathrm{H} / \mathrm{C}$ ratio of coal. Therefore, to convert coal into liquid products it is necessary to increase the $\mathrm{H} / \mathrm{C}$ ratio in the products compared with the original coal. This is accomplished by direct hydrogenation or by removal of carbon. Indirect liquefaction processes involve the gasification of coal in a fixed or fluidized bed reactor followed by conversion of the synthesis gas into liquid hydrocarbons. Catalytic liquefaction processes are carried out in the presence of active catalysts to produce hydrocarbons directly, and the rehydrogenation of solvents occurs in-situ. When a catalysts is not used, the process is usually known as solvent extraction. Solvent extraction has been used for many years as a useful method to investigate coal structure. In catalytic and non-catalytic processes, coal is slurried in a coal derived solvent and heated to $400-500^{\circ} \mathrm{C}$ for varying lengths of time. Since, in non-catalytic processes, coal minerals may also play the role of catlyst, and both processes are

*Corresponding Author: aydan.aksogan@ozal.edu.tr

Received: 20.12.2019 Published: 30.12.2019 
essentially hydroliquefaction processes, the distinction between the two processes is actually not justified [10].

The material extracted from coal may be separated into various fractions according to its solubility in a particular solvent (such as hexane, toluene, THF). It was decided to use the classification of oils (soluble in hexane), asphaltenes (soluble in toluene) and preasphaltenes (insoluble in toluene) for this study [11, 12].

In the present study, liquefaction studies have been carried out non-catalytic conditions in nitrogen gas atmosphere. The effect of the enrichment process of the liquefaction products were investigated by comparing the product yields.

In the literature, there are some investigations related with the liquefaction product yields of the lignite [13-18]. However, the effect of the enrichment in liquefaction process on the properties of the obtained products has not been fully studied yet.

\section{MATERIALS AND METHODS}

\subsection{Material}

The lignite sample used in this research was acquired from Arguvan-Malatya, which is located in the Eastern Anatolia of Turkey. The lignite samples are prepared according to the ASTM standards (ASTM D3173, ASTM D3174 and ASTM D3175) for gross calorific value, proximate and elemental analysis.

\subsection{Method}

The spiral tests were performed using by Reichert spiral with 5-launders. The tests have been done at different size fractions $(-3.35+2,-2+1.18$ and $-1.18+0.15 \mathrm{~mm})$, solid/liquid ratio $(7.5,15,25$ and $35 \%$ solid by wt.) and splitter settings $\left(90,120\right.$ and $\left.150^{\circ}\right)$. The cleanest coal obtained as a result of these experiments was used for liquefaction [19].

The samples were ground and the -106 micron size fraction was employed for liquefaction. Tetrahydrofuran (Merck, 99.0\%), tetralin (Merck, 98\%), n-hexane (Riedel-de Haen, 95\%), toluene (Riedel-de Haen, 99.7\%), ethylene glycol (EG), acetone, and ethanol were used in the present study. Liquefaction experiments were done using a mechanically stirred and electrically heated closed system $500 \mathrm{~cm}^{3}$ stainless-steel Parr reactor (PARR-USA Brand Model 4575). For each experiment, $30 \mathrm{~g}$ of the coal were put into the Parr autoclave and $90 \mathrm{~cm}^{3}$ of tetralin $\left(\mathrm{C}_{10} \mathrm{H}_{12}\right)$ without any catalyst was added on it, and the autoclave was sealed and the pressure was adjusted to 20 bar by $\mathrm{N}_{2}$. Autoclave was heated at about $3-4{ }^{\circ} \mathrm{C} / \mathrm{min}$ and waited for 2 hours at $400{ }^{\circ} \mathrm{C}$. It was mixed at constant speed of $400 \mathrm{rpm}$ during both heating and reaction. The autoclave was heated until $400^{\circ} \mathrm{C}$ at $60 \mathrm{~min}$, and then cooled to the room temperature into an ice-water bath. The char, asphaltene (AS), preasphaltene (PAS), and oil were separated from each other using the Soxhlet solvent extraction and evaporator system. The flow chart for the classification of coal dissolution products is given in Figure 1. Total conversions of liquefaction products were calculated according to the results of solvent extraction and char yields. The effect of the enrichment on the properties of the liquefaction products and oil yield were determined using mass balance equations.

Characterization and chemical structure of the liquefaction products have been determined using CHNS Elemental analyzer device (Leco CHNS 932, LECO Corporation, St. Joseph, MI), IKA C-1 calorimeter, Agilent Technologies $6890 \mathrm{~N}$ Network GC System model gas chromatography, and Agilent Technologies 5973 inert Mass Selective Detector mass spectrometer (Agilent Technologies, Santa Clara, CA) at the laboratory of Inonu University Scientific and Technology Center Research. 


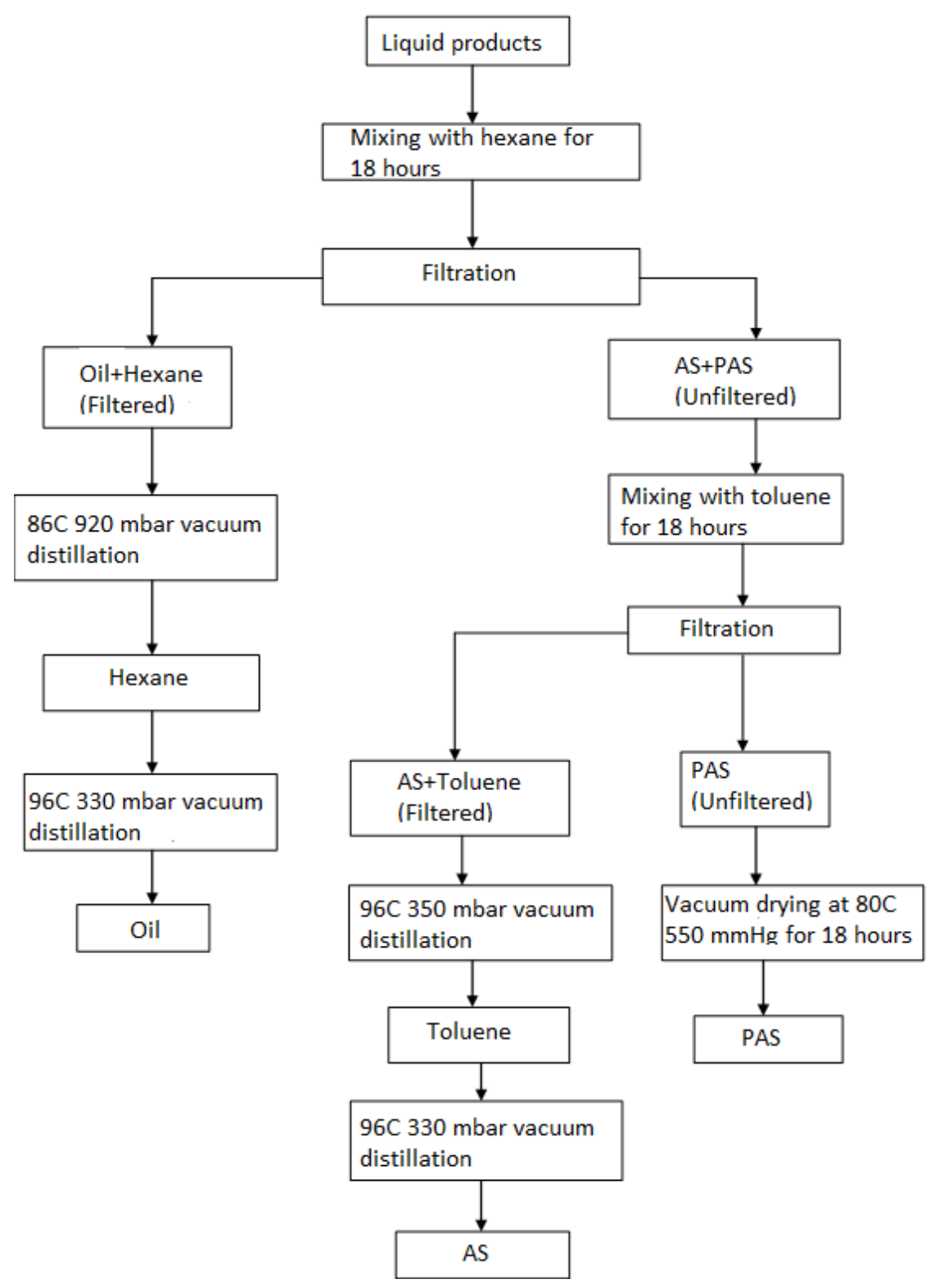

Figure 1. Flow chart of coal liquefaction products

\section{RESULTS AND DISCUSSION}

The results of the proximate and elemental analysis of raw and clean coal of Arguvan lignite and char are given in Table 1 and Table 2, respectively.

As it is seen from Table 1, raw coal contains $37.77 \%$ ash and $28.61 \%$ fixed carbon (on air dried basis). The gross calorific value of the raw coal was determined as $2576 \mathrm{kcal} / \mathrm{kg}$, whereas clean coal contains $26.51 \%$ ash and $61.20 \%$ fixed carbon. The gross calorific value of the clean coal was determined as $4180 \mathrm{kcal} / \mathrm{kg}$. The results of raw coal analysis are consistent with the research results in the literature [20]. 
Aksoğan Korkmaz and Bentli / Eskişehir Tech. Univ. J. of Sci. and Technology A-Appl. Sci. and Eng. 20 (4) - 2019

Table 1. Proximate and elemental analysis results of raw and clean coal of Arguvan lignite (on air dried basis)

\begin{tabular}{lll}
\hline Component & Raw coal & Clean coal \\
\hline Moisture (\%) & 7.96 & 2.13 \\
Ash (\%) & 37.77 & 26.51 \\
Volatile matter (\%) & 25.66 & 10.16 \\
Fixed C (\%) (by difference) & 28.61 & 61.20 \\
Total S (\%) & 3.85 & 2.08 \\
Elemental analysis & & \\
C (\%) & 31.80 & 60.07 \\
H (\%) & 2.24 & 5.44 \\
N (\%) & 0.66 & 0.48 \\
S (\%) & 3.88 & 1.97 \\
O (\%) (by difference) & 61.42 & 32.04 \\
H/C molar ratio & 0.85 & 1.09 \\
Calorific value & & \\
Kcal/kg & 2576 & 4180
\end{tabular}

Table 2. The proximate analysis results of the char of raw and clean coal

\begin{tabular}{lll}
\hline Char & Raw coal & Clean coal \\
\hline Ash (\%) & 20.11 & 10.88 \\
Volatile matter (\%) & 27.03 & 23.81 \\
Fixed C (\%) (by difference) & 52.86 & 65.31
\end{tabular}

According to the data given in Table 2, raw coal char contains $20.11 \%$ ash and $52.86 \%$ fixed carbon. Clean coal char contains $10.88 \%$ ash and $65.31 \%$ fixed carbon. These ash and fixed $\mathrm{C}$ values are quite good compared to raw coal.

The elemental analysis results of the liquefaction products (char, preasphaltane and oil) of raw and clean coal are given in Table 3. Elemental analysis and calorific values of asphaltene products can not be determined due to the difficulty of removing them from glass systems and the amount of material is small.

As it is seen from Table 3, there was an increase in the fixed carbon and calorific values of all liquefaction products in clean coal. However, it has been determined that all products have an increase in $\mathrm{H} / \mathrm{C}$ ratios.

Therefore, it can be said that the enrichment process has a positive effect on liquefaction products.

In Table 4, the yields and total conversions of the products obtained as a result of liquefaction of raw and clean coal are given. 
Aksoğan Korkmaz and Bentli / Eskişehir Tech. Univ. J. of Sci. and Technology A-Appl. Sci. and Eng. 20 (4) - 2019

Table 3. Elemental analysis results of the liquefaction products of raw and clean coal

\begin{tabular}{|c|c|c|c|c|c|c|}
\hline & $\begin{array}{c}\text { Raw coal } \\
\text { char }\end{array}$ & $\begin{array}{c}\text { Clean coal } \\
\text { char }\end{array}$ & $\begin{array}{c}\text { Raw coal } \\
\text { preasphaltane }\end{array}$ & $\begin{array}{c}\text { Clean coal } \\
\text { preasphaltane }\end{array}$ & $\begin{array}{c}\text { Raw coal } \\
\text { oil }\end{array}$ & $\begin{array}{c}\text { Clean coal } \\
\text { oil }\end{array}$ \\
\hline \multicolumn{7}{|c|}{ Elemental analysis (\%) } \\
\hline $\mathrm{C}$ & 54.16 & 66.75 & 69.02 & 73.28 & 70.30 & 79.13 \\
\hline $\mathrm{H}$ & 4.59 & 6.72 & 5.44 & 7.57 & 6.94 & 8.15 \\
\hline $\mathrm{N}$ & 1.39 & 1.30 & 1.21 & 1.33 & 0.42 & 0.33 \\
\hline$S$ & 2.92 & 2.03 & 1.05 & 0.78 & 0.44 & 0.28 \\
\hline $\mathrm{O}$ & 36.94 & 23.20 & 23.28 & 17.04 & 21.90 & 12.11 \\
\hline $\mathrm{H} / \mathrm{C}$ & 1.02 & 1.21 & 0.95 & 1.24 & 1.19 & 1.24 \\
\hline \multicolumn{7}{|c|}{ Calorific value (Kcal/kg) } \\
\hline & 8175 & 8389 & 8319 & 8549 & 4400 & 4638 \\
\hline
\end{tabular}

Table 4. The yield and total conversions of the products obtained as a result of liquefaction of raw and clean coal

\begin{tabular}{cccccc}
\hline Yield (\%) & Char & Preasphaltane & Asphaltane & Oil+Gas & Total conversion \\
\hline Raw coal & 52.43 & 8.87 & 8.33 & 30.37 & 47.57 \\
Clean coal & 43.15 & 14.18 & 8.32 & 34.55 & 56.85 \\
\hline
\end{tabular}

According to the data give in Table 4, while preasphaltane and oil+gas yields increased in clean coal, the asphaltane yield was unchanged. The total conversion of clean coal has increased from $47.57 \%$ to $56.85 \%$.

According to GC-MS analysis, chemical compounds of oils are given in Table 5. As it is seen from Table 5, the main compounds of the oil were determined as saturated n-alkenes, isoprenoids, branched alkenes, n-alkyl cyclohexane, terpene and other aromatic structures, like the literature data [12, 21-24].

As a result, it is determined that the enrichment process has a positive effect especially on the yield of the preasphaltene and oil + gas products. However, the enrichment was found to have no effect on the composition of the oil product.

Table 5. GC-MS analysis of the oil obtained from liquefaction of raw and clean coal and the detected compounds in the oil structure

\begin{tabular}{|c|c|c|c|c|c|}
\hline \multicolumn{2}{|c|}{$\begin{array}{l}\text { Retention time } \\
(\text { min) }\end{array}$} & \multicolumn{2}{|c|}{ Probable Compound } & \multicolumn{2}{|c|}{$\begin{array}{l}\text { Abundance } \\
(\%)\end{array}$} \\
\hline $\begin{array}{l}\text { Raw } \\
\text { coal }\end{array}$ & $\begin{array}{c}\text { Clean } \\
\text { coal }\end{array}$ & Raw coal & Clean coal & $\begin{array}{l}\text { Raw } \\
\text { coal }\end{array}$ & $\begin{array}{c}\text { Clean } \\
\text { coal }\end{array}$ \\
\hline 7.114 & 7.112 & Toluene & Toluene & 2.22 & 3.62 \\
\hline 25.491 & 25.520 & $\begin{array}{l}\text { Naphthalene, } \\
\text { 1,2,3,4-tetrahydro- }\end{array}$ & $\begin{array}{l}\text { Naphthalene, } \\
1,2,3,4 \text { - tetrahydro- }\end{array}$ & 59.33 & 57.73 \\
\hline 27.528 & 27.528 & $\begin{array}{l}\text { 2-Etilene,2-Ethyl-2,3-Dihidro- } 1-\mathrm{H}- \\
\text { Indan,2-Ethylindan }\end{array}$ & $\begin{array}{l}\text { 2-Etilene,2-Ethyl-2,3-Dihidro-1-H- } \\
\text { Indan, 2-Ethylindan }\end{array}$ & 0.61 & 0.62 \\
\hline 31.287 & 31.293 & $\begin{array}{l}\text { Azulene } \\
\text { Naphthalene }\end{array}$ & $\begin{array}{l}\text { Azulene } \\
\text { Naphthalene }\end{array}$ & 31.36 & 27.81 \\
\hline 32.632 & 31.628 & $\begin{array}{l}\text { Naphthalene,1,2,3,4-tetrahydro-1- } \\
\text { propile }\end{array}$ & $\begin{array}{l}\text { Naphthalene,1,2,3,4-tetrahydro-1- } \\
\text { propile }\end{array}$ & 0.84 & 0.86 \\
\hline 35.619 & 35.625 & $\begin{array}{l}\text { Naphthalene, 2-metil- } \\
\text { Naphthalene, 1-metil- }\end{array}$ & $\begin{array}{l}\text { Naphthalene, 2-metil- } \\
\text { Naphthalene, 1-metil- }\end{array}$ & 0.46 & 0.42 \\
\hline 37.215 & 37.221 & $\begin{array}{l}\text { Naphthalene, 2-metil- } \\
\text { Naphthalene, 1-metil- }\end{array}$ & $\begin{array}{l}\text { Naphthalene, 2-metil- } \\
\text { Naphthalene, 1-metil- }\end{array}$ & 1.16 & 0.90 \\
\hline 38.394 & 38.406 & Butylhydroxytoluene & Butylhydroxytoluene & 1.67 & 2.39 \\
\hline 62.770 & 62.776 & Benzene,1,3-Diethyl-5-Methyl & Benzene,1,3-Diethyl-5-Methyl & 0.44 & 0.35 \\
\hline 68.440 & 68.452 & Benzene,1-Ethinyl & Benzene,1-Ethinyl & 1.44 & 1.37 \\
\hline 88.639 & 78.826 & 2-Methyl & 2-Methyl & 1.32 & 1.19 \\
\hline
\end{tabular}




\section{CONCLUSION}

As a conclusion, it can be said that in the liquefaction studies with raw coal, char yield was $52.43 \%$, preasfaltene yield was $8.87 \%$, asphaltene yield was $8.33 \%$ and oil + gas yield was $30.37 \%$. As a result of the liquefaction of the clean coal, the char yield decreased by $9.28 \%$, the preasphaltene yield increased by $5.31 \%$ and the oil + gas yield increased by $4.18 \%$, while the asphaltene yield remained unchanged. Total conversion increased from $47.57 \%$ to $56.85 \%$ (Table 4 ).

It has been determined that all products have reduced sulfur content (Table 3 ). The calorific value of all products in clean coal have increased (for char from $8175 \mathrm{kcal} / \mathrm{kg}$ to $8389 \mathrm{kcal} / \mathrm{kg}$, for preasphaltene from $8319 \mathrm{kcal} / \mathrm{kg}$ to $8549 \mathrm{kcal} / \mathrm{kg}$, for oil from $4400 \mathrm{kcal} / \mathrm{kg}$ to $4638 \mathrm{kcal} / \mathrm{kg}$ ).

According to GC-MS results, the main compounds of the oil were determined as naphthalene and its derivatives, tetraline, azulene, binaphthalene and benzen. In the oil of clean coal, no compounds were found that did not exist in raw coal. As it is seen from Table 4, the clean coal oil yield for liquefaction process was founded as $34.55 \%$ to be higher than the raw coal oil yield (30.37\%). From these results, it has been found that the enrichment process has a strong positive effect on the liquefaction product yields, especially on the oil + gas and preasphaltene.

Finally, it has been suggested that the production of a more valuable product using the lignite having low calorific value is not only going to contribute more to the country's economy but also be better for the environment. However, it is clear that it is necessary to investigate the economics of the theoretically and practically possible liquefaction method.

\section{ACKNOWLEDGEMENTS}

This work was financially supported by the Inonu University Scientific Research Projects Coordination Unit. (Project number: BAP-2015-34)

\section{REFERENCES}

[1] Coal Information 2017, IEA 2018.

[2] MTA 2017 Annual Report, Ankara, MTA 2018.

[3] Lievens C, Ci D, Bai Y, Ma L, Zhang R, Chen J.Y, Gai Q. A study of slow pyrolysis of one low rank coal via pyrolysis-GC/MS. Fuel Processing Technology 2013; 116:85-93.

[4] Xu Y, Zhang Y, Wang Y, Zhang G, Chen L. Gas evolution characteristics of lignite during lowtemperature pyrolysis. Journal of Analytical and Applied Pyrolysis 2013; 104:625-631.

[5] Meng F, Yu J, Tahmasebi A, Han Y, Zhao H, Lucas J, Wall T. Characteristics of chars from lowtemperature pyrolysis of lignite. Energy Fuels 2013; 28:275-284.

[6] He Q, Wan K, Hoadley A, Yeasmin H, Miao Z. TG-GC-MS study of volatile products from Shengli lignite pyrolysis. Fuel 2015; 156:121-128.

[7] Li P, Zong Z.M, Liu F.J, Wang Y.G, Wei X.Y, Fan X, Zhao Y.P, Zhao W. Sequential extraction and characterization of liquefaction residue from Shenmu-Fugu subbituminous coal. Fuel Processing Technology 2015; 136:1-7.

[8] Rahman M, Adesanwo T, Gupta R, Klerk A. Effect of direct coal liquefaction conditions on coal liquid quality. Energy and Fuels 2015; 29:3649-3657. 
Aksoğan Korkmaz and Bentli / Eskişehir Tech. Univ. J. of Sci. and Technology A-Appl. Sci. and Eng. 20 (4) - 2019

[9] Kanca A, Dodd M, Reimer J.A, Uner D. Following the structure and reactivity of Tunçbilek lignite during pyrolysis and hydrogenation. Fuel Processing Technology 2016; 152:266-273.

[10] Kural O. Coal Resources, Properties, Utilization, Pollution. Istanbul, Turkey: Ozgun Press, 1994.

[11] Ekinci E, Yardim F, Razvigorova M, Minkova V, Goranova M, Petrov N, Budinova T. Characterization of liquid products from pyrolysis of subbituminous coals. Fuel Processing Technology 2002; 77-78:309-315.

[12] Karaca H, Koyunuoğlu C. The co-liquefaction of Elbistan lignite and biomass Part II: The characterization of liquefaction products. Energy Sources, Part A: Recovery, Utilization and Environmental Effects 2010; 32:1167-1175.

[13] Gözmen B, Artok L, Erbatur G, Erbatur O. Direct liquefaction of high-sufur coals: effects of the catalyst, the solvent and the mineral matter. Energy and Fuels 2002; 16:1040-1047.

[14] Hesenov A, Gül Ö, Gafarova P, Erbatur O, Schobert H.H. Distribution of main product fractions in co-liquefaction of high-sulfur lignites blended with petroleum heavy bottoms. Prepr.Pap.Am.Chem.Soc., Div.Fuel Chem. 2004; 49:500-502.

[15] Gül Ö, Gafarova P, Hesenov A, Schobert H.H, Erbatur O. Catalytic direct liquefaction of high sülfür lignites: temperature and solvent effect on product distributions. Prepr.Pap.-Am.Chem.Soc., Div.Fuel Chem. 2004; 49:559-561.

[16] Omais B, Courtiade M, Charon N, Thiebaut D, Quignard A. Characterization of oxygenated species in coal liquefaction products: An overview. Energy and Fuels 2010; 24:5807-5816.

[17] Li X, Xue Y, Feng J, Yi Q, Li W, Guo X, Liu K. Co-pyrolysis of lignite and Shendong coal direct liquefaction residue. Fuel 2015; 144:342-348.

[18] You Q, Wu S.Y, Wu Y.Q, Huang S, Gao J.S, Shang J.X, Min X.J, Zheng H.A. Product distributions and characterizations for integrated mild-liquefaction and carbonization of low rank coals. Fuel Processing Technology 2017; 156:54-61.

[19] Aksoğan Korkmaz A. The effects of enrichment methods on pyrolysis product yields obtained from different lignites. Ph.D.Thesis, Inonu University, Malatya, Turkey, 2017.

[20] İçel İlhan. Malatya-Arguvan tertiary basin lignite prospecting report. MTA Reports, Ankara, 1988.

[21] Speight J.G. The Chemistry and Technology of Coal. 2nd ed. New York, NY, USA: Marcel Dekker Inc., 1994.

[22] Methakhu, S, Ngamprasertsith S, Prasassarakich P. Improvement of oil yield and its distribution from coal extraction using sulfide catalysts. Fuel 2007; 86:2485-2490.

[23] Karaca H, Koyunuoğlu C. Co-liquefaction of Elbistan lignite and biomass Part I: The effect of the process parameters on the conversion of liquefaction products. Energy Sources, Part A: Recovery, Utilization and Environmental Effects 2010; 32:495-511.

[24] Wang Z, Shui H, Pan C, Li L, Ren S, Lei Z, Kang S, Wei C, Hu J. Structural characterization of the thermal extracts of lignite. Fuel Processing Technology 2014; 120:8-15. 